\title{
ПРОБИОТИЦИ В ХРАНЕНЕТО ДНЕС
}

\author{
Р. Еникова
}

\section{PROBIOTICS IN CURRENT NUTRITIONAL PRACTICES}

\author{
R. Enikova
}

Рез юме. Пробиотииите днес се прилагат като част от терапевтичната стратегия при лечението на много заболявания. Приемът им е чрез функиионални храни и в състава на разнообразни хранителни суплементи. В статията е направен преглед на семействата и родовете микроорганизми, сред които има шамове с пробиотичен потенциал - Lactobacillus, Bifidobacteria, Propionibacteria, Leисопоstoc и много други. Формулирани са функиионалните, биохимични и физиологични свойства и ефекти върху организма, които определят здравните претенции на пробиотичните храни и суплементи апатогенност, адхезия върху лигавиците, хипохолестеролемичен, антимикробен, имуногенен, антиканиерогенен и други ефекти, дължаши се на нормализиране на балансите в интестиналния микробиом. Представени са изискванията на Codex Alimentarius към методологията за определяне на пробиотичните свойства на щамовете. Цитирани са оригинални пробиотични храни, традииионни за различни страни и региони на света, както и съвременните функиионални храни, съдържащи пробиотищи и имащи голямо здравно-профилактично значение и за здравото население. Направен е кратък преглед на заболявания, при които приемът на пробиотици успешно допълва ефектите на класическите терапевтични процедури.

$\boldsymbol{S} \boldsymbol{u} \boldsymbol{m} \boldsymbol{m}$ a ry. Currently probiotics are implemented as constituents of the therapeutic strategy in the treatment of numerous diseases. Their intake is realized through functional foods and as ingredients of various food supplements. The paper presents an overview of microorganisms families and species incorporating strains with probiotic potential - - Lactobacillus, Bifidobacteria, Propionibacteria, Leuconostoc and many others. The functional, biochemical and physiological properties and effects on the organism determining the health claims of probiotic foods and supplements are formulated-apathogenicity, adhesion on mucosa, hypocholesterolemitting, antimicrobial, immunogenic, anticarcinogenic and other effects due to the normalization of balances in the untestinal microbioma. Codex Alimentarius requirements to the methodology for determination of strains probiotic features are presented. Original probiotic foods are quoted, traditional for various countries and regions in the world, as well as current functional foods containing probiotics that are of great importance for the health prevention targeted of healthy population as well. A brief review is presented of diseases where probiotics intake successfully contributes to the effect of classic therapeutic procedures.

$\Pi$ 1 реди 113 години в Женева, Швейцария, в лабораторията на професор Massol, блестящият млад български учен Стамен Григоров открива Lactobacillus bulgaricus, водещия микроб на българското кисело мляко и с това полага началото на темата за пробиотиците в храните. Тя е развита впоследствие по-подробно от Иля Илич Мечников в института „Пастьор“ в Париж [11]. След тях поколения български учени изследват пробиотичните свойства на бактериите на българското кисело мляко. А научната общност в света и днес търси, открива и изучава и много други пробиотици.

Един от най-ярките представители на българските учени в областта на пробиотиците е Мария Стефанова-Кондратенко (19282018). Тя продължава идеята на д-р Стамен Григоров и на И. Мечников в България, създава българската национална колекция от млечнокисели микроорганизми и закваски за оригинални млечни продукти, на първо място - за българското ки-

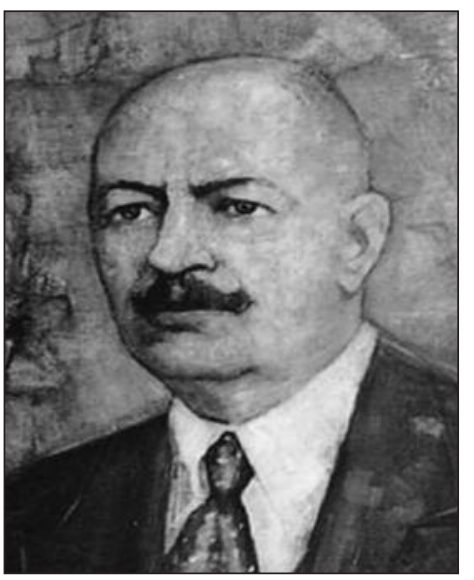

Стамен Григоров

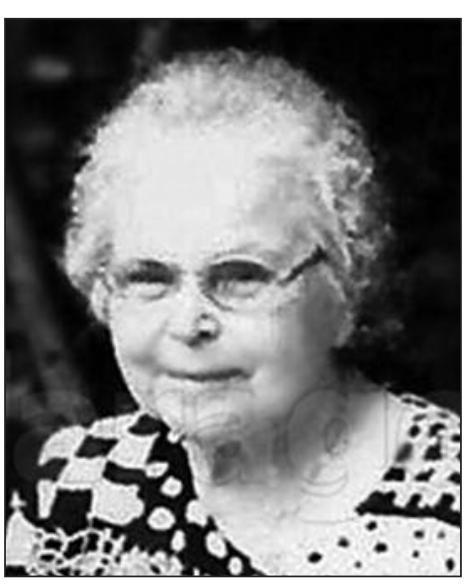

Мария Стефанова-Кондратенко село мляко. През целия си живот работи с клиницисти и специалисти в експерименталната медицина по здравословните ефекти на Lactobacillus bulgaricus, включително и при създаването на пробиотични функционални храни за деца в кърмаческата и ранната детска възраст [11]. Мария Стефанова-Кондратенко е създател на Централната лаборатория за чисти култури към ДСО „Млечна промишленост“, наследник на която е ELBY-Bulgaricum. Учениците и последователите ѝ в млекарската наука следват нейните принципи за тясно сьтрудничество с медицинската колегия при проучванията на индивидуалните функционални свойства и пробиотичния потенциал на различни щамове млечнокисели микроорганизми. Науката в света понастоящем усилено изучава и прилага пробиотиците вече като неизменна част от терапевтичната стратегия при лечението на много заболявания посредством функционални храни и хранителни суплементи.

Най-известното определение, давано за пробиотиците, принадлежи на Fuller R., (1989): ,Живи организми, които, добавени с храната, оказват положителен ефект върху организма-гостоприемник чрез подобряване на баланса на неговата интестинална микрофлора“. Определението на СЗО дава по-тесни граници на здравословния характер на пробиотиците: „Непатогенни за човека бактерии, притежаваши антагонистична активност към патогенни и условно-патогенни бактерии и осигуряващи възстановяването на нормалната микрофлора “. Много изчерпателна е дефиницията, дадена за пробиотиците в стандарта на Русия - страна, в която темата е обект на всестранно теоретично изучаване и традиционно широко приложение. Така в него се казва: „Живи непатогенни, нетоксигенни микроорганизми, постъпващи в храносмилателния канал на човека с храната, благотворно въздействащчи на неговия организъм и нормализиращии състава и биологичната активност на микрофлората на храносмилателния тракт" [12].

Пробиотичен потенциал имат много видове микроорганизми от различни семейства и родове. Например в 
Genus Lactobacillus такива свойства са проявявани от щамове L. delbrueckii spp. Bulgaricus, L.acidophilus, L.fermentum, L. plantarum, L.rhamnosus, L.reuteri, L. casei, L. paracasei, L.brevis, L.gasseri, L. jhonsoni, L.kefiri, L.helveticus. Като пробиотични в Genus Bifidobacterium са посочвани B. вifidum, B.adolescentis, B.catenulatum, B.longum, B.lactis. B Genus Streptococcus пробиотичен потенциал е описван при $S$. thermophilus и $S$. lactis. Сред дрождите са посочвани Saccharomyces cerevisiae, Saccharomyces boulardii и Candida kefiri. Пробиотични щамове са описвани и сред бактерии от родовете Propionibacterium, Leuconostoc (L.lactis, L.citreum, L.mesenteroides), Enterococcus, дори Bacillus, както и някои апатогенни Enterobacteriaceae. Списъкът на примерите далеч не е изчерпателен.

В основата на здравните претенции към пробиотичните микроорганизми са редица техни функционални и физиологични свойства и ефекти [13]:

- безусловна апатогенност за човека;

- отсъствие на токсични метаболити;

- устойчивост към храносмилателните секрети и преодоляване на стомашната бариера;

- способност да адхезират и временно да се имплантират и колонизират върху лигавицата в чревния канал;

- ендогенна продукция на дизахаридази - $\beta$-галактозидазна (лактазна) активност с облекчаване на синдрома на лактозната нетолерантност при вроден или придобит лактазен дефицит;

д деконюгация на жлъчните киселини и хипохолестеролемичен ефект;

- антимикробен ефект срещу патогенни и гнилостни микроорганизми;

синергизъм с нормалните чревни симбионти, възстановяване и поддържане на чревната еубиоза;

- ендогенна биосинтеза на витамини (напр. В12);

- активиране на имуногенезата - IgG, IgM, IgA, фагоцитарни реакции и др.;

редуциране на алергиите към млечен белтък; ния апарат;

- благоприятно влияние върху моториката на чрев-

- инхибиране на ендогенната биосинтеза на карциногенни метаболити;

- протективен ефект при карциногенеза.

При проявата на изложените физиологични свойства и ефекти има силно изразена видова и щамова индивидуалност. Ефектът от приложението на пробиотици се постига постепенно, той не се проявява при инцидентен перорален прием. Необходимо е постъпването в организма да бъде системно за продължителен период от време, а дозите на пробиотичните микроорганизми - достатъчно масивни. Така в българското кисело мляко, което е класически естествен функционален пробиотичен продукт, според съответния български стандарт количеството на лактобацилите е нормирано на не по-малко от $10^{7}$ жизнеспособни клетки в $1 \mathrm{~g}$ продукт, а на термофилните стрептококи - не по-малко от $10^{8}$ [10]. На практика бактериите на двата симбионта често са значително повече. В периода на прием пробиотичните микроорганизми се заселват в лумена и върху лигавиците на различни чревни сегменти, размножават се, метаболизират, влизат в синергични взаимовръзки с микробиома на индивида и тогава оказват съответните физиологични ефекти.

В ръководството "Guidelines for the Evaluation of Probiotics in Food" CЗО/ФАО, Canada, 2002 г., се поставя много сериозно въпроса за медицинската мотивировка на приложението на всеки един щам и се препоръчва строго определена методология, включваща сериозни експериментални изследвания in vitro и in vivo преди обявяването му за пробиотичен. Тази методология изисква информация и научни доказателства за следните щамови характеристики [6]:
> подробна таксономична идентификация на щама до род/вид/щам чрез генотипни и фенотипни методи; регистрирането му в международно призната колекция на чисти култури микроорганизми;

р резистентност към киселинността на стомашен сок;

- резистентност към жлъчни киселини;

- способност да адхезира върху мукозата на храносмилателния канал;

> антимикробна активност спрямо потенциално патогенни микроорганизми;

- ефект на препятстване на адхезията на патогенни микроорганизми;

- хидролиза (деконюгация) на жлъчни соли;

- резистентност към спермициди (за вагиналните пробиотици);

- оценка на безопасността на щама в тестове in vitro, върху опитни животни и в проучвания върху човека;

- дублирано, рандомизирано, плацебо-контролирано проучване на ефекта от приложението в две групи пациенти при хора; желателни са и повторения на проучването.

Препоръчва се ефективността на приложение на пробиотика да бъде сравнена с тази при стандартно лечебно третиране. Безусловно важно е да бъде доказано, че щамът е безвреден и безопасен за човека и не притежава патогенни свойства. Тази безопасност изисква особено внимание и е в обсега на специален надзор от Европейския орган за безопасност на храните (EFSA), който системно наблюдава и ежегодно попълва листата на микроорганизмите, прилагани в храните въз основа на задълбочени анализи на риска [7, $8,9]$.

През 2015 г. в Брюксел е основана Международната пробиотична асоциация „Европа“ (IPA „Еurope“). Нейният доклад от м. май 2018 г. допълва Ръководството на СЗО/ФАО от 2002 г., като уточнява изискванията към: определението за „пробиотик“; таксономията на щама, мястото му в систематиката на микроорганизмите, определено по съвременни молекулярни методи; необходимата научна документация, включително за резултатите от клинични изпитвания; жизнеспособността на микроорганизмите в предлаганите пробиотични продукти $[3,4]$.

„Пробиотични“ са храните, ферментирали или заквасени с различни щамове пробиотични микроорганизми. Сред тях първото място заема млякото, следвано от плодови или зеленчукови, зърнени, соеви или оризови ферментирали продукти и напитки. Главно достойнство на заквасените храни е високото съдържание на жизнеспособни клетки на пробиотиците, което осигурява приема на масивни дози биологично активни клетки на микроорганизмите. Те преодоляват стомашната бариера, заселват се временно в лумена и върху лигавицата на червата, метаболизират и влизат в синергични взаимодействия с нормалните интестинални симбионти и така осъществяват гореизложените физиологични въздействия. Не трябва да се забравят индивидуалните реакции на организма като поносимост към различните пробиотични храни и степен на проява на здравословните ефекти.

Голяма част от пробиотичните храни са с древна история и от много векове са традиционни в храненето на много народи. Примерите са много: българското кисело мляко, известно в света като „йогурт“, кефирът, ацидофилните млека, много видове сирена - чедар, гауда, саламурени, плесенни и др.; квасеното зеле, туршиите от ябълки, домати, краставички, корейското кимчи, зелените маслини, соевото тесто „темпе“, японската соева супа „мисо“, черният шоколад, ферментиралият чай „комбуча“, кумисът в Монголия и Казахстан. Във всички тях се съдържат бактерии или микроскопични гъбички с повече или по-малко изразени биологични свойства, близки до пробиотичните. 
Най-голям е делът на заквасените млечни храни Codex Alimentarius към ФАО/СЗО представя следната класификация на най-разпространените традиционни ферментирали млечни продукти [1]:

\begin{tabular}{|c|c|}
\hline $\begin{array}{l}\text { Наименование на } \\
\text { продуктите }\end{array}$ & Специфична микрофлора \\
\hline Йогурт ( Yogurt) & $\begin{array}{l}\text { Симбиотични култури на Streptococcus thermop- } \\
\text { hilus и Lactobacillus delbrueckii spp. bulgaricus }\end{array}$ \\
\hline $\begin{array}{l}\text { Ацидофилно мляко } \\
\text { (Acidophilus Milk) }\end{array}$ & Lactobacillus acidophilus \\
\hline Кефир (Kefir) & $\begin{array}{l}\text { Стартерни култури, приготвени от кефирни зър- } \\
\text { на, Lactobacillus kefiri; видове от рода Leuconos- } \\
\text { toc; Lactococcus и Acetobacter в строго специ- } \\
\text { фични взаимодествия; дрожди, не ферменти- } \\
\text { ращи лактозата (Saccharomyces omnisporus, } \\
\text { Saccharomyces cerevisiae и Saccharomyces exi- } \\
\text { guous) }\end{array}$ \\
\hline $\begin{array}{l}\text { Кумис (Kumys) } \\
\text { (заквасено коби- } \\
\text { лешко мляко) }\end{array}$ & $\begin{array}{l}\text { Lactobacillus delbrueckii spp. bulgaricus u Kluive- } \\
\text { romyces marxiamus }\end{array}$ \\
\hline $\begin{array}{l}\text { Омекотен йогурт } \\
\text { (Mild Yogurt) }\end{array}$ & $\begin{array}{l}\text { Култури на Streptococcus thermophilus и на други } \\
\text { Lactobacillus, различни от Lactobacillus delbru- } \\
\text { eckii, spp. bulgaricus }\end{array}$ \\
\hline
\end{tabular}

В допълнение към тази класификация са множеството съвременни заквасени с различни пробиотични щамове млечни храни - бифидопродукти и други, в които най-често се използват комбинирани стартерни култури, съдържащи по няколко пробиотични щама с различни допълващи се свойства.

Населението на България има привилегията да поставя ежедневно на трапезата си българското кисело мляко, известно в света като „йогурт“. Така то получава постоянно и в естествено големи дози жизнеспособните микроорганизми на симбиотичната закваска - Lactobacillus delbrueckii, spp.bulgaricus \& Streptococcus thermofilus, с несъмнено доказани пробиотични достойнства. В последните години млечната промишленост в страната ни предоставя на населението внушителен брой асортименти обогатено биологично подкиселено мляко, съдържащо, освен L. delbrueckii, spp. bulgaricus и S. thermophiles, и други пробиотични видове-L.acidophilus, Bifidobacterium (B.actiregularis), L.reuteri, L.rhamnosus, L.kefiri, щамове от родовете Lactococcus и Sacharomyces и други. Нерядко този тип продукти имат характер на синбиотици освен заквасването с комбинация от няколко пробиотични щама, в тях се добавят плодови, зърнени съставки или пребиотици - баластни фибри и олигозахариди. Български закваски се изнасят в много страни на света. Примерите за млечни храни, произведени с тях, са много. Един такъв пример e „Мейджи-йогуртът“, разпространен в цяла Азия - Япония, страните на Индокитайския полуостров, Китай. С този продукт местното население, което е с конституционален лактазен дефицит и съответна непоносимост към млякото, получава благословената възможност да включва този незаменим природен продукт в ежедневното си хранене.

Пробиотичните храни намират приложение при разнообразни патологични състояния с инфекциозна, но и неинфекциозна етиология [13]. Това могат да бъдат инфекциозни ентероколити от бактерии, вируси и паразити, но също така синдромът на раздразненото черво, улцерозните колити и други чревни патологии с дискинезии, диария, метеоризъм, обстипации, електролитен дисбаланс, хипотрофии, алергии. Пробиотиците нормализират алкално-киселинния баланс, благоприятно повлияват чревния пасаж и са приложими при хронични стресови обстипации или при пациенти в напреднала възраст. Незаменима е ролята им в патологии с вродени и придобити малабсорбции на дизахариди, аминокиселини и други нутриенти. Пример за това е благотворното влияние на лактобацилите при лактазен дефицит и съответна малабсорбция на лактозата, наблюдавани като вродени и много по-често като придобити в лека и умерена форма, развиващи се с възрастта (особено при народите от Скандинавските страни, Китай, Индокитай, Япония, Екваториална Африка). Сред всички народи и популации се наблюдава и геронтологична лактозна малабсорбция. В това отношение млечнокиселите храни, заквасени с щамове, активно отделящи $\beta$-галактозидази, нямат аналог, отделяйки ензима в тънкото черво, разграждайки лактозата до глюкоза и галактоза, които се резорбират в този сегмент и не достигат до ко̀лона, където биха предизвикали бурна ферментация и диариен синдром.

Важно свойство на някои пробиотици е конституивната им способност да деконюгират жлъчните киселини и от тази гледна точка да стимулират биодеградацията на холестерола - основа на наблюдавания хипохолестеролемичен ефект и свързания с него проблем за съвременна хранителна профилактика на хиперлипопротеинемиите, респ. атеросклерозата.

Пробиотици се прилагат и при пациенти, подлагани на антибиотична терапия, химиотерапия, льчелечение, при радиационна болест с неизбежните дисбиотични последствия. Благоприятно въздействие имат при имунодефицитни състояния и колагенози. Повлияват усвоимостта на калция и се препоръчват и при остеопороза.

Що се отнася до активирането на имуногенезата и протективните антитуморни свойства спрямо карциногенезата, то това би било резултат от системен продължителен прием на пробиотици с експериментално доказани такива ефекти. За лактобацилите на българското кисело мляко са получени немалко доказателства в полза на позитивните имуногенни и противотуморни въздействия $[2,5,15]$.

Отделно специално място заемат биологично подкиселените адаптирани млека и детските млечни храни, съдържащи пробиотични микроорганизми, най-често L.acidophilus, L. delbrueckii, spp.bulgaricus и Bifidobacteria. Допълнително изискване към щамовете в случая е те да бъдат продуценти на L-оптичния изомер на млечната киселина. Пробиотичните храни за кърмачета и деца в ранна възраст се прилагат при вродени и придобити ензимопатии, при алергии, при симптоми на дисбиоза - колики, метеоризъм, запек или диария. Най-ефективното средство при храненето на кърмачета и деца с тежки, протрахирани чревни разстройства и хипотрофии с инфекциозна, главно вирусна етиология, са делактозираните детски диетични млека, заквасени с подходящи пробиотични щамове.

Пробиотичните микроорганизми в храните се развиват в естествената си среда, където клетките им са в активно жизнеспособно състояние. В различните форми на суплементите, съдържащи пробиотични микроорганизми, последните са подлагани на въздействия като лиофилизация, изсушаване, таблетиране или други методи. Това не би могло да не оказва влияние върху микробните клетки и би изисквало поне по-продължителна адаптация в условията на чревния канал. Но това е друга тема...

И в края на това изложение особено необходимо е да подчертаем следното: пробиотиците не са лекарствени средства. Те нямат непосредствено фармакологично въздействие, не са препарати за симтоматично лечение при гореизложените патологични състояния, не са в състояние незабавно да облекчават страданията на пациента. Етиката задължава лекаря да изясни това правило, когато препоръчва приема на пробиотични храни или суплементи. Наред с това етиката изисква пациентът да бъде подходящо информиран за отдалечените благоприятни въздействия върху еубиозата, респ. нормализирането на свързаните с нея функции на организма. 
От друга страна производителите следва много прецизно да етикетират пробиотичните храни, като обявяват присъствието на пробиотичен щам с неговата точна таксономична характеристика, минимума на съдържащи се в него жизнеспособни клетки, срока и условията на съхранение [1]. Забранява се използването на информация, която би подвела потребителя или би приписала лечебни свойства на продукта. Последното условие е задължително законодателно изискване, поставено в Регламент (ЕО) № 1924/2006 на Европейския парламент и на Съвета от 20 декември 2006 г. относно хранителните и здравни претенции за храните [14].

\section{Библиография}

1. Codex Alimentarius. Standart for fermented milks, CXS 243-2003, Adopted in 2003. Revised in 2008, 2010, 2018. 12 p.

2. Donchev N. \& R. Enikova. Antitumor Effect of Dietary Regimens Including Sour-Milk Products Fermented by Original Bulgarian Strains. Biotechnology \& Biotechnological Equipment, 1992, $6: 2$, p. 43-47

3. IPA „EUROPE“. Criteria to qualify a microorganism designated as "probiotic' in foods, beverages and dietary supplement“. May 2018 [http://www.ipaeurope.org/].

4. IPA Europe guidelines to qualify a microorganism to be termed as 'probiotic' in foods, beverages and supplements in commercial communications, 2015.

5. Ivanova T., M.Jekova. Preventive role of lyophilic dairy products bulgaricum and biostim. Cancer letters 114, 1997, p. 93-95.

6. Joint FAO/WHO Working Group Report on Drafting guidelines for the evaluation of probiotics in food. London, Ontario, Canada. May 2002.
7. European Food Safety Authority (EFSA). Scientific Colloquium-Microorganisms in Food and Feed: Qualified Presumption of Safety. 13-14 December 2004, Brussels, Belgium.

8. Health and Nutritional Properties of Probiotics in Food including Powder Milk with Live Lactic Acid Bacteria. Report of a Joint FAO/WHO Expert Consultation on Evaluation and Nutritional Properties of Probiotics in Food including Powder Milk with Live Lactic Acid bacteria. Cordoba, Argentina, 1 -4 October 2001.

9. The 2016 updated list of QPS status recommended biological agents in support of EFSA risk assessments. EFSA Journal 2017;15(3):4664, p. 1-4

10. БДС 12-2010. Българско кисело мляко.

11. Българското име на дълголетието. 100 години от откриването на Lactobacillus bulgaricus. Сб. Фондация „Стамен Григоров““. С., 2005, Изд. „Принт сервиз 97“ USBN 954-90367-2-3

12. ГОСТ Р 56139-2014 Продукты пищевые функциональные. Методы определения и подсчета пробиотических микроорганизмов.

13. Еникова Р. Пробиотиците в съвременното хранене. В сб. «Функционални храни, хранителни добавки, хранителни технологии», под ред. Б.Попов, София, 2006, изд. Филвест, с. 40-47

14. Регламент (ЕО) № 1924/2006 на Европейския парламент и на Съвета от 20 декември 2006 г. относно хранителните и здравни претенции за храните. Официален вестник на EC, L 404/9, 18.01.2007, с. 244-256.

15. Цоневски Д., Р. Еникова, П. Салчев. Щамова индивидуалност на протективния ефект на закваски за българско кисело мляко при експериментална туморогенеза. Човекът и неговата жизнена среда, 1999, XXII, c. 19-27.

А. Антор

Пословиците и поговорките са обект на все по-голямо внимание. Обособява се дял от езикознанието - паремиология, която ги изучава. Пословиците се определят като кратки словесни изрази, или „клишета“ с характер на завършено изречение (като напр. „Цървули няма, гайда $u c \kappa a ")$, , поговорките - като незавършени изречения, синтактичната цялост на които се допълва от контекста (напр. „... като кучето на нивата“).

Народът отдавна е разбрал това свръхценно деформиращо въздействие на неовладяния страх върху възприятно-предствната, мисловната и паметовата дейност, като го е отразил в пословиците: „Страхът има големи очи“; „Страхбт гледа на едро“; „Страхът много види“.

... Свръхценните форми на реагиране са видове човешки реакции, при които възникват свръхценни страхови мисли, респ. страхови паралогични обрати на мисълта, не са убягнали на психологичното прозрение на народа, който ги е отразил в поговорки, като: „Когато е хапала змия, той се бои и от гущер“; ,Парен каша духа“; „Парен тиква духа“; „Парен каща расол духа“; „Парен петел и от дъжд бяга“; „Попарено куче и от дъжд бяга“.

Трябва да бъде отбелязано, че народната мъдрост не само предупреждава за въображаемите опасности, които сврахценното мислене вижда (т.е. за отрицателните страхови свръхщенни идеи, но също така и за измамните пътища, по които то понякога „намира“ спасение от една реална опасност (т.е. за измамните положителни свръхценни идеи). Това е отразено в поговорката „Давещиият се лови за сламка“"

... Свръхценни агресивни реакции спрямо по-слаби същества или срещу предмети са особено чести в детската възраст. Те далеч не са редки и при възрастни. Интересна тяхна разновидност са агресивните реакции, които се наблюдават понякога (при съответна личностова структура) при преживявания за малоценност вследствие на телесна или психична непълноценност на собствената личност. Народната мъдрост познава и тази закономерност на човешките реакции, която е изразила в поговорките: „Оm крив и кривоглед, и кривонос Господ да пази“; „От квосе далеч се дргж“".

... „Привилегията“ на силните да бъдат сърдити тогава, когато трябва да се признаят за виновни, е отразена и в известната крилата фраза „Гневиш се, Юпитере, значи не си прав“. Тя е отбелязана също в древноиндийското петокнижие „Панчатантра“ в следните стихове:

Под славата на своя трон

не се замисля изарят много.

Като разбунен, весел слон,

понесен, всичко тәпче строго.

Но случи ли се след това,

надут да падне сред бедите -

не свойта глупава глава

той обвинява, а - слугите.

... Улесняващото въздействие на глада върху агресията е често отбелязано: „Глад глава загубя“; , „Глад дружина издава“; „Глад не види нищо освен хляб“; „Глад очи няма“; „Глад село пали“; „Глад сестра продава“; „Глад срам не познава“; „Гладен вблк и всред село влязва“.

\section{Коста Заимов, „Афективни параадаптивни реакиии на личността", изд. Медицина и физкултура, 1988}

